$\xi=1$

\title{
Lactic acid bacteria and identification with PCR-DGGE
}

\author{
BİÇER Yusuf *, UÇAR Gürkan \\ Selcuk University Faculty of Veterinary Medicine Department of Food Hygiene and Technology \\ *Corresponding author E-mail: yusufbicer@selcuk.edu.tr
}

\begin{abstract}
Lactic acid bacteria (LAB) are an important group in the industrially using microorganisms. The first pure cultures of bacteria was "Bacterium lactis" (probably Lactococcus lactis), obtained in 1873 by J. Lister. LAB are Gram-positive, non motile, non spore-forming, except Sporolactobacillus inulinus, catalase negative, microaerophilic or anaerobic microorganisms. LAB can be found in milk and dairy products, plants and human and animal intestinal mucosa. LAB have low Guanine and Cytosine $(\mathrm{G}+\mathrm{C})$ ratio.

The industrial applications of lactic acid bacteria is considered, it is emphasized that reliable typing methods in strain levels are getting important about both study on cultures used in functional foods and determining the performance of LAB starter cultures. Denaturing Gradient Gel Electrophoresis (DGGE) is the most common technique in molecular fingerprinting culture-independent techniques. The technique is based on the separation of the same length but having different sequences of the Polymerase Chain Reaction (PCR) products.
\end{abstract}

Keywords: Lactic Acid Bacteria; Molecular Identification; PCR-DGGE.

\section{Introduction}

Lactic acid producing bacteria are the most important group among microorganisms of industrial significance. Definition of lactic acid producing bacteria is equivocal in general. The reason for that lies in an historical tradition rather than presence of an exact description of the term. The historical origin of the term dates back to pre-twentieth century. The first pure bacterial culture was obtained in 1873 by J.Lister, which was "Bacterium lactis" (probably Lactococcus lactis). After discovery of similarities between the bacteria that turn the milk sour and the lactic acid producing bacteria obtained from different sources, significant improvements happened regarding classification of these bacteria. However, the conceptual confusion continued until publication of the study by Orla-Jensen on this subject. This study had significant influence on systematic of lactic acid bacteria, and despite major revisions, the basic classification was preserved over the years. Orla Jensen considered the following criteria while establishing the classification:

a) Morphology (coccus or bacillus)

b) Glucose fermentation type (homo-hetero fermentation)

c) Growth at certain principal temperatures $\left(10-40{ }^{\circ} \mathrm{C}\right)$

d) Sugar utilization rates

Lactic acid bacteria constitute a group among Gram positive bacteria with their morphological, metabolic and physiological characteristics. The term "lactic acid bacteria" can be defined as bacteria that are responsible for fermentation of food and animal feed, including the bacterial flora of a healthy mucosal surface in animals and human (Axelsson 2004).

Utilization of culture-independent techniques in food microbiology dates back to the end of 1990's, and since then they have been used frequently. These methods are not dependent on cultures, and they target nucleic acid (DNA, RNA) to identify a population within a certain ecosystem (Cocolin et al. 2013). Molecular microbiology is a rapidly advancing field of science. A major branch of this field involves demonstration and identification of microor- ganisms in their natural ecosystems. It has been proposed that molecular methods can help to overcome the problems encountered during selective reproduction and isolation of bacteria from samples using traditional methods. The major cause for the requirement of culture-independent techniques is that for most bacteria, it is not known what conditions are necessary for reproduction in their natural environment, and that developing the growthmedia that will provide these conditions is difficult. Moreover, molecular methods are rapid and reliable (Ercolini 2004). Nonetheless, studies have shown that simultaneous use of cultureindependent and cultural methods produce more accurate results in terms of microbial diversity (Kesmen et al. 2012).

\section{Lactic acid bacteria}

\subsection{General characteristics}

Lactic acid bacteria (LAB) have great significance in food technology, because they are common in nature, they are the cause of the commonly observed deterioration in various foods, and they play important roles in production and ripening of some foods (Con \& Gokalp 2000).

LAB are Gram positive, immotile, catalase negative, microaerophilic or anaerobic microorganisms, and they do not produce spores except Sporolactobacillus inulinus. LAB may be present in milk and dairy products, plants, and intestinal mucosa of human and animals. They are almost never present in water or soil. Apart from lactic acid, LAB also produce antimicrobial substances such as hydrogen peroxide, bacteriocin and $\mathrm{CO}_{2}$ (Akcelik 2000). Among Gram positive bacteria, LAB constitute a group that has low proportion of guanine and cytosine $(\mathrm{G}+\mathrm{C})$ (Ludwig et al. 1993).

Besides being predominant in the natural flora of the frequently consumed fermented food products, LAB produce exopolysaccharide, are used as a starter culture in food production, and are present in probiotic products (Rebecci et al. 1998). 
LAB constitute twelve genera of microorganisms, they are: Aerococcus, Carnobacterium, Enterococcus, Lactobacillus, Lactococcus, Leuconostoc, Oenococcus, Pediococcus, Streptococcus, Tetragenococcus, Vagococcus and Weissella. LAB are classified according to their capacity to metabolize carbohydrates to lactic acid. Accordingly, those that metabolize most glucose to lactic acid are called homofermentative, and those that produce ethanol, acetic acid and $\mathrm{CO}_{2}$ in addition to lactic acid by metabolizing glucose are called heterofermentative LAB. Homofermentative LAB metabolize $85 \%$ or greater percentage of the glucose to lactic acid. This group of bacteria utilize glucose via fructose diphosphate (Embden-Meyerhof-Parnas) pathway. Heterofermentative LAB metabolize only $50 \%$ of glucose to lactic acid, and additionally they produce ethanol, acetic acid and $\mathrm{CO}_{2}$. This group of bacteria utilize 6phosphogluconate/phosphoketolase pathway during fermentation (Erkmen 2011).

\subsection{Fermentation}

Humans have preserved their food since Neolithic age $(10,000$ BC) using various methods including fermentation (Prajapati \& Nair 2003). The scientific basis of fermentation was understood after Van Leeuwenhoek and Hooke discovered microorganisms in 1665 (Gest 2004). During 1850-60's, Pasteur confuted "spontaneous generation theory" in well-designed experiments (Wyman 1862). Sir John Lister demonstrated the role of a single bacteria in fermented milk, "Bacterium" lactis (Lactococcus lactis) in 1877 The word fermentation originates from the Latin word (fervere) that means boiling; Pasteur described it as "life without air" ("La vie sans l'air"). In biochemical terms, fermentation is a metabolic process for production of energy from organic compounds without contribution of any exogenous oxidizing agent. Fermentation serves for different roles in the process of food production. Major accepted roles are:

a) Preserving foods by lowering water activity (through drying or use of salts), and formation of inhibitory substances such as organic acids (lactic acid, acetic acid, formic acid, propionic acid), ethanol and bacteriocin

b) Enhancement of food safety via prevention of pathogen development or elimination of toxic compounds, Enhancement of nutritional value

c) Enhancement of organoleptic properties of food (Gaggia et al. 2011)

\section{Molecular approach to food analysis}

Culture-independent techniques were initially used in the field of food microbiology at the end of 1990's, and since that time, they have been used commonly. These methods target nucleic acids (DNA, RNA) for identification, and follow changes that take place in populations present in a specific ecosystem (Cocolin et al. 2013).

Considering the industrial utilization of LAB, reliable strain-based typing methods has gained importance regarding both determination of LAB starter culture performance and examination of cultures that will be used as an additive in functional foods (Kiran \& Osmanagaoglu 2011).

Molecular techniques have been used effectively during the recent 20 years for identification and characterization of the predominant species in environments containing complex microbial populations, such as in fermented foods.

One important point to consider for accurate identification of the microbial profile in a food ecosystem is the selection of the DNA region that will be amplified. The target gene should have two principal properties:

1) It should be present in all members of the examined population,
2) It should have preserved regions allowing design of international primers, and also variable regions where differentiation is possible.

Genes that encode ribosomal RNA (rRNA) are classified in this category. Various regions of the gene encoding 16S rRNA are frequently targeted for bacteria, whereas the gene encoding $26 \mathrm{~S}$ rRNA is frequently targeted for yeasts. An important advantage to utilization of these two genes is that large sequence database is available (Fogel et al. 1999).

PCR-based molecular techniques have particularly been shown as fast and reliable methods for identification and classification of LAB.

Although it is possible to define separate LAB species with physiological and biochemical properties, it has been reported that these properties are not enough for further classification within a given species. Furthermore, it has been noted that wide variations exist between populations of succeeding generations of many species, and therefore it is important to determine gene sources and confirm the correctness of the species at all stages of the investigation. The inadequacy of classical and modern microbiological methods in identification has led the researchers to directly focus on the genetic material (Kiran 2006).

Food ecosystem is not a stable environment. Growth, survival and biochemical reaction dynamics of the microorganisms in food occur in response to the physical and chemical changes $(\mathrm{pH}$, salt, temperature) in microenvironment of food, capacity of microorganisms to colonize in food matrix, development in heterogenous environment (micro-colonies and biofilms) and in situ cell-cell interaction generally in solid media. Therefore, it is important to consider microorganism dynamics when establishing reliable, quantitative microbiological data from food. These information are key to understanding the behavior of pathogen microorganisms and particularly LAB (Fleet 1999).

\section{Survival mechanisms and stress reactions of micro- organisms}

It is widely accepted that cultural techniques reveal only a minority of the microorganisms present in natural ecosystems. This can be explained by two main factors:

1) New microorganisms that cannot be reproduced via known growth media,

2) Limitations in detection of microorganisms under stress or in viable but non-culturable (VNBC) phase (Fleet 1999).

VBNC phase is triggered by stress factors such as unavailability of food, low temperature and $\mathrm{pH}$, and heat application. In this phase, healthy and culturable microorganisms maintain their metabolic functions, but they cannot form colonies in growth media (selective or non-selective). It has been detected in the natural environment of Gram positive and negative species, and was also demonstrated experimentally in several food pathogens (Roszak \& Colwell 1987, Fleet 1999) and Enterococcus faecalis (del Mar Lleo et al. 2000).

\subsection{Denaturing gradient gel electrophoresis}

Denaturing gradient gel electrophoresis (DGGE) is the most frequently used molecular fingerprint technique among cultureindependent techniques. DGGE was initially used to identify the microbial ecosystem of fermented foods such as sucuk (Turkish style fermented sausage) and cheese, and later it was utilized in the process of microbial degradation. In the recent years, it has been commonly used in fermented foods of Asia, Africa and North America (Cocolin et al. 2013). This technique is based on separation of the polymerase chain reaction (PCR) products that have similar length but different nucleic acid sequence. In microbiology field, ribosomal DNA PCR-DGGE was first used by Muyzer et al. in 1993. Since then, it has been frequently preferred to demonstrate microbial diversity by many researchers (Ercolini 2004). 
Application of PCR-DGGE to food microbiology first started in 1999 with a study by Ampe et al., in which they examined the distribution of microorganisms in Mexican pozol, fermented maize dough (Ampe et al. 1999, Ercolini 2004).

Food fermentation is a process where microorganisms belonging to many different species and genera are in competition and various microbial conversions take place. It has been shown that it is possible to follow the dynamic changes occurring during food fermentation and identify the dominant microbial populations using DGGE. This potential was demonstrated by Cocolin et al. (2007) in their study related with optimization of DGGE procedures via utilization of different primers, different denaturation gradients and different electrophoresis conditions. Although RNA is not widely used in DGGE studies, when selected as target region, it can provide important clues for discrimination of LAB that are used as starter culture particularly in fermented dairy products from LAB that are not used as starter (Fox et al. 2004).

\subsubsection{Working principle}

DGGE is the molecular method with most extensive use for identification of complex microbial populations. It is based on electrophoretic separation of PCR products of double stranded DNA (dsDNA) through a polyacrylamide gel containing chemical gradient (urea and formamide) denaturing agents. When DNA molecule is subjected to appropriate denaturing gradient, the dsDNA goes under partial denaturation depending on the sequence. The change in DNA conformation results in slower migration of the molecule. Separation of molecules that have similar length but different nucleic acid sequence based on their denaturation (melting) profiles was described theoretically by Fisher and Lerman in 1983. When the method is used for identification of microbial profile, DNA molecules that are present as a complex mixture following amplification are separated and characterized (Cocolin et al. 2013).

Denaturation conditions in acrylamide gel is provided by urea and formamide. A $100 \%$ chemical denaturant contains $7 \mathrm{M}$ urea and $40 \%$ formamide. In order to create a gradual denaturant gradient from low to high density in the gel, low and high density denaturation solutions are prepared and mixed with acrylamide, and the mixture is poured in between glass plates. A comb is placed to create sample wells, and the gel is allowed to form polymer structure over time. Electrophoresis is carried out at a constant temperature between $55-65{ }^{\circ} \mathrm{C}$, usually $60{ }^{\circ} \mathrm{C}$. The principles of the electrophoretic technique used to separate DNA, RNA and protein molecules are also valid here. During denaturation of dsDNA, fragments gradually denature at the sites called "melting domains", and as a result, dsDNA is converted to ssDNA. Melting domains are areas comprised of base sequences that melt at same temperatures. Melting temperature is $\left(\mathrm{T}_{\mathrm{m}}\right)$ sequence-specific. When the lowest melting temperature is reached, branched "nicked" molecules form, and partial melting occurs. This slows the migration of DNA in acrylamide gel. Thus, DNA fragments that have similar length but different sequences create different appearance in the denaturing gradient. DNA fragments with different sequences form melting areas with different $T_{m}$ and migrate at different distances in the DGGE gel. (Ercolini 2004, Kacmaz 2009).

Before DGGE analysis of DNA fragments, their melting behavior should be determined. Moreover, in order to achieve better separation of the fragments, electrophoresis time and gradient should be optimized.

DGGE can be performed with horizontal or vertical denaturing gradient gels. In vertical gels, denaturing gradient is perpendicular to the direction of electrophoresis, and it is usually used for determining melting behavior and optimum denaturation proportion of DNA fragments. Only a single sample, or PCR products whose melting behavior will be determined are run on vertical gels.

In parallel DGGE, denaturing gradient is parallel to the electrical field, and denaturant range is narrowed to achieve better separation. Parallel gels are often preferred because they enable multiple samples to be run at the same time. To achieve maximum separation, electrophoresis time should be determined prior to the analysis of samples. For this purpose, each sample is loaded with certain time intervals, and electrophoresis time is determined. This is called "time travel experiment" (Myers et al. 1987, Ercolini 2004). Samples loaded onto DGGE gel are generally PCR products. The highest resolution in the gel is obtained when molecules do not completely lose their double stranded structure. For that matter, addition of 30-40 guanine-cytosine (GC) piece to one of the PCR primers used for amplification of 16S rDNA fragments helps to keep the DNA partially double stranded, and the target region to stay in the lowest melting area. This sequence, which is added to 5 ' end of one of the PCR primers and consists of guanine and cytosine, acts like a high melting domain, and prevents dsDNA to completely denature and convert to ssDNA (Muyzer \& De Waal 1993).

Band profiles in DGGE can be visualized with ethidium bromide. Alternatively, SYBR Green I may be used. The advantage of SYBR Green I is that it does not cause background stains and therefore allows detection of DNA fragments with less density. In their study titled "Concurrent use of cultural and cultureindependent techniques for identification of lactic microflora in sucuk", Kesmen et al. (2012) reported that simultaneous use of these two techniques yielded more effective and accurate results. According to their results, while Lactococcus piscium, Weissella halotolerans, Staphylococcus succinus, Staphylococcus piscifermentans, Staphylococcus condimenti, Staphylococcus carnosus were only identified with culture-independent techniques, Lactobacillus plantarum, Leuconostoc mesenteroides and Leuconostoc citreum were only identified using cultural methods. In another study titled "Detection of the lactic acid bacteria in commercial yoghurt by PCR-denaturing gradient gel electrophoresis" Ma et al. (2009) noted that PCR-DGGE has the capacity for discrimination at the species level, but is insufficient for discriminating viable and dead cells, and that cultural and cultureindependent techniques should be used in combination to have detailed information about microbial population. Sofu and Ekinci (2016) conducted a study for determining the bacterial diversity of Turkish Ezine Cheese by PCR-DGGE and Single Strand Conformation Polimorphism analysis. They found Lc. lactis group and Str. thermophilus as dominant members of the cheese flora by DGGE. Rychlik et al. (2017) published a study about traditional Polish cheese; Wielkopolska. The dominant eukaryotic community of this traditional product was shown to be composed of Galactomyces geotrichum, Kluyveromyces marxianus, Pichia kudriavzevii, Candida inconspicua, and Trichosporon spp. by PCR-DGGE.

\section{Conclusion}

Although cultural methods still maintain their gold standard value in food analysis, it is evident today that there are species that cannot be identified with these methods. Thus, studies have shown that combined use of these methods with culture-independent molecular techniques would yield more accurate information about bacterial microflora present in foods.

\section{References}

[1] Akcelik M (2000) Gida Mikrobiyolojisi ve Uygulamaları, Genişletilmiş 2. Baskı, Ankara, Sim Matbaacılık, pp. 357-363.

[2] Ampe F, Ben Omar N, Moizan C, Wacher C \& Guyot, JP (1999) Polyphasic study of the spatial distribution of microorganisms in Mexican pozol, a fermented maize dough, demonstrates the need for cultivation-independent methods to investigate traditional fermentations, Appl Environ Microbiol 659, 5464- 5473.

[3] Axelsson L (2004) Lactic Acid Bacteria: Classification and Physiology. In: Lactic Acid Bacteria Microbiological and Functional Aspects Revised and Expanded. Eds: Salminen S, von Wright A, Ouwehand A, 3rd ed. New York, Basel: Marcel Dekker, pp: 20-87. https://doi.org/10.1201/9780824752033.ch1. 
[4] Cocolin L, Diez A, Urso R, Rantsiou K, Comi G, Bergmaier I \& Beimfohr C (2007) Optimization of conditions for profiling bacterial populations in food by cultureindependent methods. International Journal of Food Microbiology 120, 100-109. https://doi.org/10.1016/j.ijfoodmicro.2007.06.015.

[5] Cocolin L, Alessandria V, Dolci P, Gorra R \& Rantsiou K (2013) Culture independent methods to assess the diversity and dynamics of microbiota during food fermentation. International Journal of $\begin{array}{lll}\text { Food } \quad \text { Microbiology } & \text { 29-43. }\end{array}$ https://doi.org/10.1016/j.ijfoodmicro.2013.05.008.

[6] Con AH \& Gokalp HY (2000) Laktik Asit Bakterilerinin Antimikrobiyel Metabolitleri ve Etki Şekilleri. Türk Mikrobiyoloji Cemiyeti Dergisi 30(3-4), 180-190.

[7] Del Mar Lleò M, Pierobon S, Tafi MC, Signoretto C \& Canepari $\mathrm{P}$ (2000) mRNA detection by reverse transcription-PCR for monitoring viability over time in an Enterococcus faecalisviable but nonculturable population maintained in a laboratory microcosm. Appl Environ Microbiol 66, 4564-4567. https://doi.org/10.1128/AEM.66.10.4564-4567.2000.

[8] Ercolini D (2004) PCR-DGGE fingerprinting: novel strategies for detection of microbes in food. Journal of Microbiological Methods 56, 297-314. https://doi.org/10.1016/j.mimet.2003.11.006.

[9] Erkmen O (2011) Gida Mikrobiyolojisi, 3.Baskı, Ankara, Efil Yayınevi, pp. 411-412.

[10] Fisher SG \& Lerman LS (1983) DNA fragments differing by single base pair substitutions are separated in denaturing gradient gels: correspondence with melting theory. Proc Natl Acad Sci USA 80, 1579- 1583. https://doi.org/10.1073/pnas.80.6.1579.

[11] Fleet GH (1999) Microorganisms in food ecosystems. Int J Food Microbiol 50, 101-117. https://doi.org/10.1016/S01681605(99)00080-X.

[12] Fogel GB, Collins CR, Li J \& Brunk CF (1999) Prokaryotic genome size and SSU rDNA copy number: estimation of microbial relative abundance from a mixed population. Microbial Ecology 38, 93-113. https://doi.org/10.1007/s002489900162.

[13] Fox PF, McSweeney PLH, Cogan TM \& Guinee TP (2004) Cheese: Chemistry, Physics and Microbiology. vol 1, 3rd edition, London, Elsevier Ltd.

[14] Gaggia F, Di Gioia D, Baffoni L \& Biavati B (2011) the role of protective and probiotic cultures in food and feed and their impact on food safety. Trends in Food Science and Technology 22, 58-66. https://doi.org/10.1016/j.tifs.2011.03.003.

[15] Gest H (2004) the discovery of microorganisms by Robert Hooke and Antoni van Leeuwenhoek, Fellows of The Royal Society. Notes and Records of the Royal Society of London 58, 187-201. https://doi.org/10.1098/rsnr.2004.0055.

[16] Kacmaz N, 2009. PCR-DGGE tekniği ile kefir mikroflorasındaki laktik asit bakterilerinin tanımlanması. Erciyes University, Graduate School of Natural Sciences, Master thesis.

[17] Kesmen Z, Yetiman AE, Gulluce A, Kacmaz N, Sagdic O, Cetin B, Adiguzel A, Sahin F \& Yetim H (2012) Combination of culturedependent and culture-independent molecular methods for the determination of lactic microbiota in sucuk. International Journal of Food Microbiology 153, 428-435. https://doi.org/10.1016/j.ijfoodmicro.2011.12.008.

[18] Kıran F (2006) Hücre duvarı protein profilleri ve pilazmid içeriklerine göre laktik asit bakterilerinin moleküler tanısı. Ankara University, Graduate School of Natural Sciences, Master thesis.

[19] Kiran F \& Osmanagaoglu O (2011) Laktik asit bakterilerinin (LAB) identifikasyonunda /tiplendirmesinde kullanılan moleküler yöntemler. Erciyes University Journal of Institute of Science and Technology 27(1), 62-74.

[20] Ludwig W, Neumaier J, Klugbayer N, Brockmann E, Roller C, Jilg S, Reetz K, Schachtner I, Ludwigsen A, Wallner G, Bachleitner M, Fischer U \& Scheleifer KH (1993) Phylogenetic relationships of bacteria. Antonie Van Leuwenhoek 64, 285-304. https://doi.org/10.1007/BF00873088.

[21] Ma J, Kong J \& Ji M (2009) Detection of the lactic acid bacteria in commercial yoghurt by PCR-denaturing gradient gel electrophoresis. Chinese Journal of Applied and Environmental Biology 15 534-539.

[22] Muyzer G, De Waal EC \& Uitterlinden AG (1993) Profiling of complex microbial populations by denaturing gradient gel electrophoresis analysis of polymerase chain reaction-amplified genes coding for 16S rRNA. Appl Environ Microbiol 59, 695- 700.

[23] Myers RM, Maniatis T \& Lerman LS (1987) Detection and localization of single base changes by denaturing gradient gel electrophoresis. Methods Enzymol 155, 501-527. https://doi.org/10.1016/0076-6879(87)55033-9.
[24] Prajapati JB \& Nair BM (2003) the history of fermented foods. In: Fermented Functional Foods. Ed: Farnworth ER, 2nd ed. Boca Raton, New York, London, Washington DC: CRC Press, pp. 1-25.

[25] Rebecchi A, Crivori S, Sarra PG \& Cocconcelli PS (1998) Physiological and molecular techniques for the study of bacterial community development in sausage fermentation. J of Appl Microbiol 84, 1043-1049. https://doi.org/10.1046/j.1365-2672.1998.00442.x.

[26] Roszak DB \& Colwell RP (1987) Survival strategies of bacteria in the natural environment. Microbiol Rev 51, 365-379.

[27] Rychlik T, Szwengiel A, Bednarek M, Arcuri E, Montet D, Mayo B Nowak J \& Czarnecki Z (2017) Application of the PCR-DGGE technique to the fungal community of traditional Wielkopolska fried ripened curd cheese to determine its PGI authenticity. Food Control 73 , 1074-1081. https://doi.org/10.1016/j.foodcont.2016.10.024

[28] Sofu A and Ekinci FY (2016) Bacterial diversity dynamics of traditional Turkish ezine cheese as evaluated by PCR-DGGE and SSCP analysis. International Journal of Dairy Technology 69(4), 592-600. https://doi.org/10.1111/1471-0307.12311.

[29] Wyman J (1862) Spontaneous generation. British Medical Journal 2, 311-312. https://doi.org/10.1136/bmj.2.90.311. 